\title{
PENGEMBANGAN SISTEM LECTIVE UNTUK LAPORAN \\ KURIKULUM PERGURUAN TINGGI \\ (Studi Kasus : Universitas Muhammadiyah Malang)
}

\section{Laporan Tugas Akhir}

Diajukan Untuk Memenuhi

Persyaratan Guna Meraih Gelar Sarjana

Informatika Universitas Muhammadiyah Malang

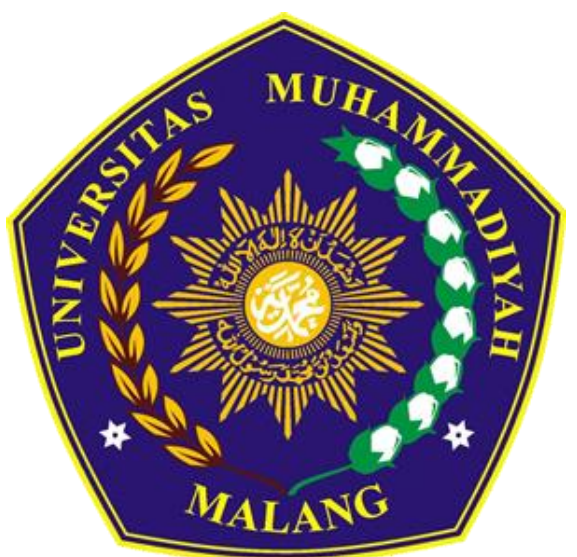

FEBRI AYU FITRIANI

(201310370311219)

Rekayasa Perangkat Lunak

PROGRAM STUDI INFORMATIKA

FAKULTAS TEKNIK

UNIVERSITAS MUHAMMADIYAH MALANG 


\section{LEMBAR PERSETUJUAN}

\section{LEMBAR PERSETUJUAN}

\section{PENGEMBANGAN SISTEM LECTIVE UNTUK LAPORAN}

KURIKULUM PERGURUAN TINGGI

(Studi Kasus : Universitas Muhammadiyah Malang)

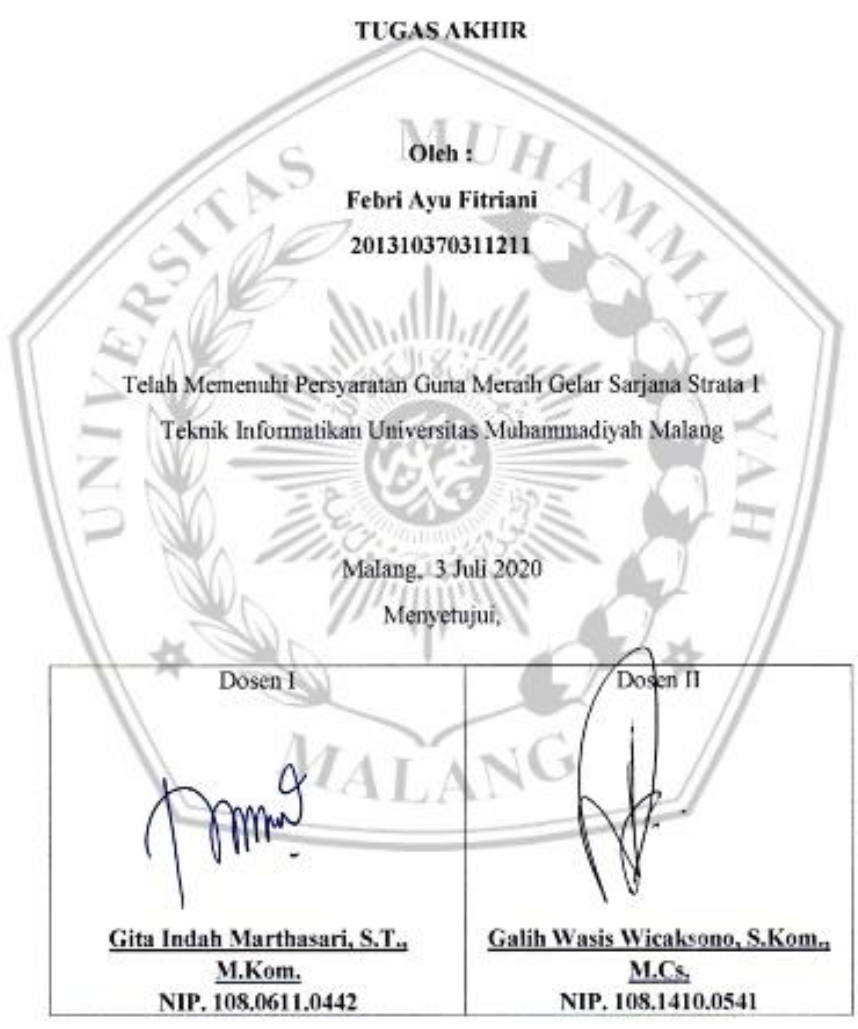




\section{LEMBAR PENGESAHAN}

\section{LEMBAR PENGFSAHAN}

\section{PENGEMBANGAN SISTEM LECTIVE UNTUK LAPORAN}

KURIKULUM PERGURUAN TINGGI

(Studi Kasus : Universitas Muhammadiyah Malang)

\section{TUGAS AKHIR}

Sebagai Persyaratan Guaa meraih Gelar Sarjana Struta 1

Program Studi Informatika Cniverșitas Muhammadiyah Malang

Disusun Oleh :

Febri Ayu Fitrian

201310370311219

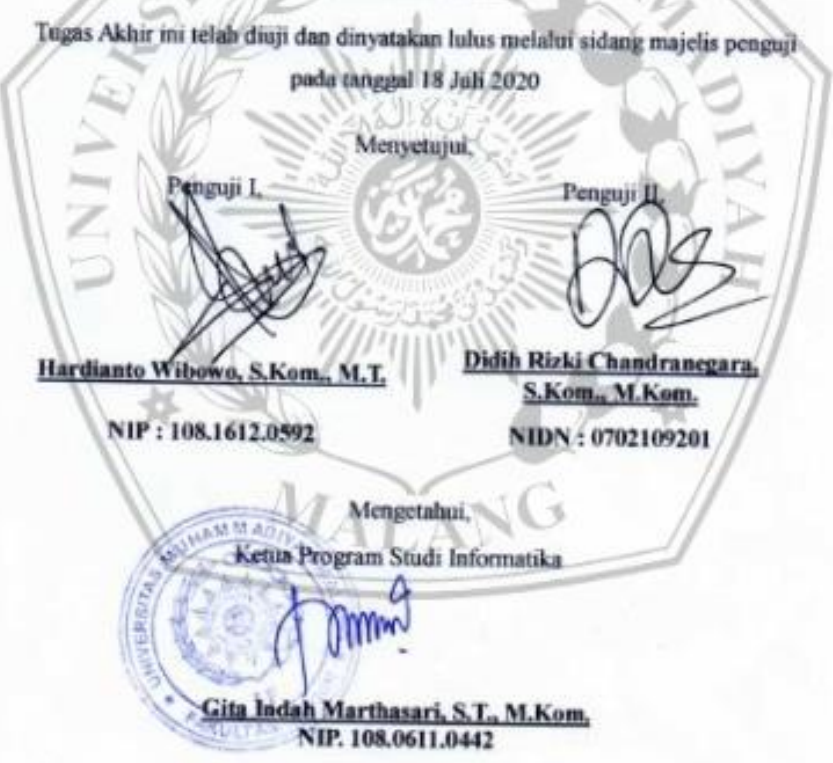




\section{LEMBAR PERNYATAAN}

\section{LEMBAR PERNYATAAN}

Yang bertanda tangan dibawah ini :
NAMA
: FEBRI AYU FITRIANI
NIM
: 201310370311219
FAK/ JUR.
: TEKNIK/ INFORMATIKA

Dengan ini saya menyatakan bahwa Tugas Akhir dengan judul "PENGEMBANGAN SISTEM LECTIVE UNTUK LAPORAN KURIKULUM PERGURUAN TINGGI (STUDI KASUS : UNIVERSITAS MUHAMMADIYAH MALANG)" beserta seluruh isinya adalah karya saya sendiri bukan merupakan karya tulis orang lain, baik sebagian maupun seluruhnya, kecuali dalam bentuk kutipan yang telah disebutkan sumbernya.

Demikian surat pernyataan ini saya buat dengan sebenar-benarnya. Apabila kemudian ditemukan adanya pelanggaran terhadap etika keilmuan dalam karya saya ini, atau ada klaim dari pihak lain terhadap keaslian karya saya ini maka saya siap menanggung segala bentuk resiko/sanksi yang berlaku.

Dosen Pembimbing

Malang, 3 Juli 2020

Yang Membuat Pernyataan

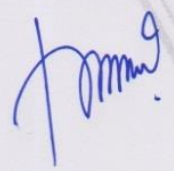

Gita Indah Marthasari, S.T., M.Kom.

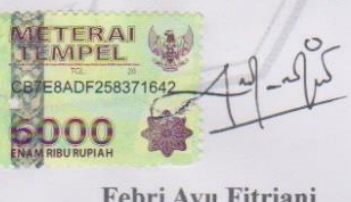

Febri Ayu Fitriani 


\section{KATA PENGANTAR}

Alhamdulillah wa syukurillah, puji syukur kehadirat Allah SWT karena telah memberikan segala rahmat serta hidayah-Nya selama ini sehingga penulis dapat menyelesaikan penelitian tugas akhir dengan judul

\section{"PENGEMBANGAN SISTEM LECTIVE UNTUK LAPORAN KURIKULUM PERGURUAN TINGGI (STUDI KASUS : UNIVERSITAS MUHAMMADIYAH MALANG)"}

Shalawat serta salam semoga selalu tercurahkan dengan melimpah kepada junjungan kita Nabi besar Muhammad saw, kepada keluarga, sahabat, serta pengikutnya hingga akhir zaman.

Dalam dokumen ini penulis memaparkan bahasan mengenai apa saja yang dilakukan untuk melakukan pengembangan pada sistem Lective yang ada, yang dalam bahasan ini memuat bagaimana menambahkan pengecekan progres RPS dan notifikasi sebagai laporan pada sistem, bagaimana analisa yang dilakukan, apa saja kebutuhan dan perancangan yang dilakukan, hingga bagaimana hasil akhir dan analisa fenomena yang terjadi, hingga kesimpulan menyeluruh yang dapat diambil dari penelitian ini.

Penulis menyadari bahwa penelitian dan penyusunan yang dilakukan dalam memenuhi tugas akhir ini memiliki banyak kekurangan dan jauh dari kata sempurna. Oleh sebab itu, penulis secara terbuka dan ikhlas menerima kritik dan saran yang dapat membangun sehingga penelitian yang dilakukan menjadi lebih baik dan dapat bermaanfat dalam perkembangan ilmu dan teknologi baik dimasa sekarang maupun selanjutnya.

Malang, 3 Juli 2020

Penulis 


\section{DAFTAR ISI}

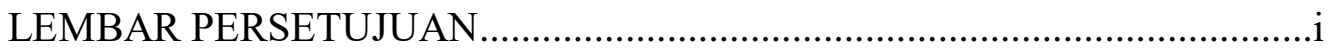

LEMBAR PENGESAHAN …......................................................................ii

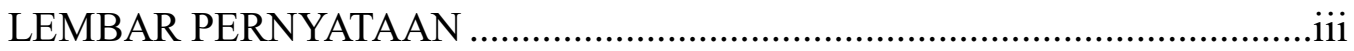

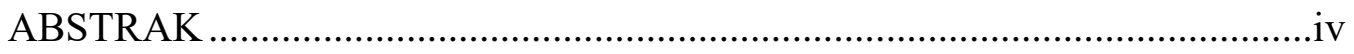

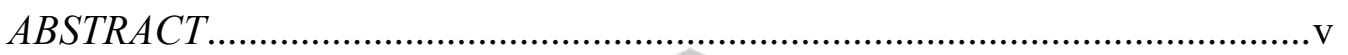

LEMBAR PERSEMBAHAN ................................................................ vi

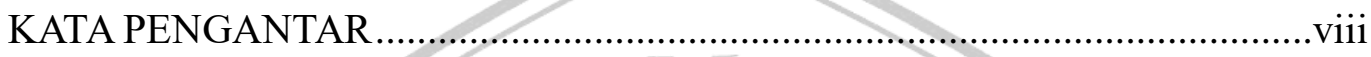

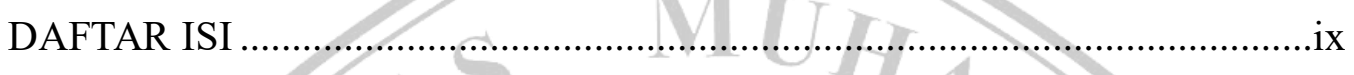

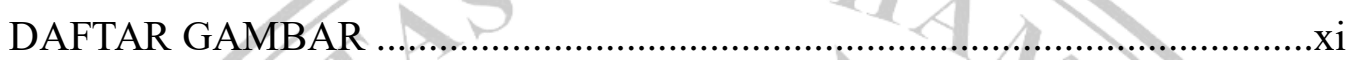

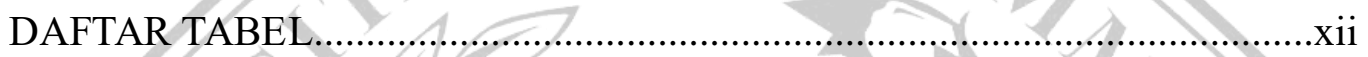

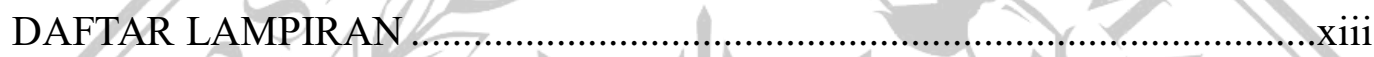

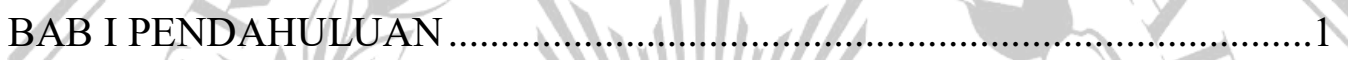

1.1 Latar Belakang ............................................................1

1.2 Rumusan Masalah .........................................................4

1.3 Tujuan Penelitian................................................................4

1.4 Batasan ...........................................................................

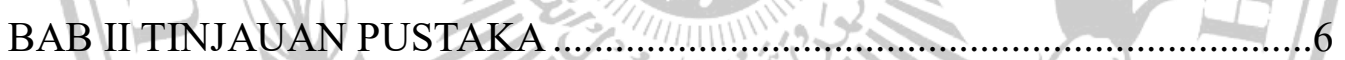

2.1 Rencana Pembelajaran Semester (RPS) ...................................6

2.2 Kelengkapan RPS Menurut Pakar...........................................8

2.3 Mata Kuliah................................................................

2.4 Business Process Improvement ..................................................10

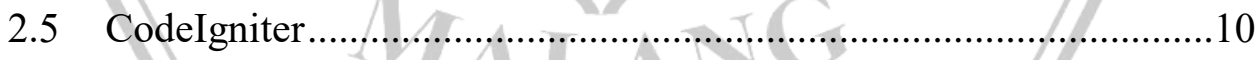

2.6 Kajian Penelitian Terdahulu .......................................................11

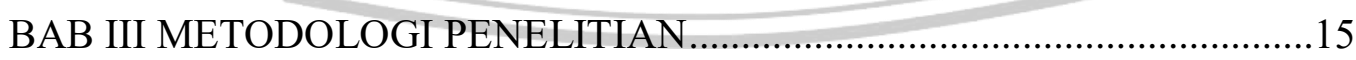

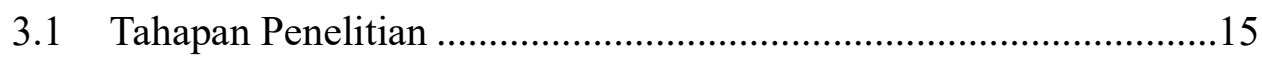

3.2 Desain Penelitian.........................................................................15

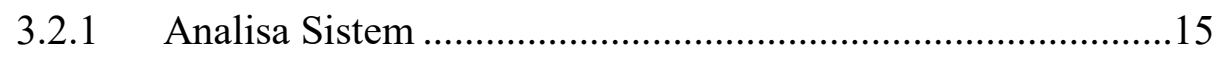

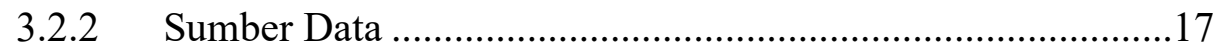

3.3 Pengujian Solusi .....................................................................18

3.4 Pengembangan Perangkat Lunak ..................................................19 
3.4.1 Analisa Kebutuhan Sistem...................................................19

3.4.2 Atribut Acuan Kelengkapan..................................................21

3.4.3 Rancangan Basis Data .......................................................25

3.4.4 Flowchart Pengecekan Kelengkapan Atribut........................25

3.4.5 Flowchart Notifikasi ...........................................................26

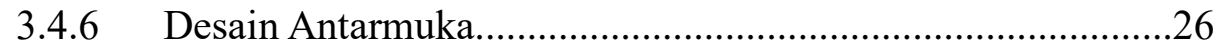

3.4.7 Rancangan Skenario Pengujian ........................................28

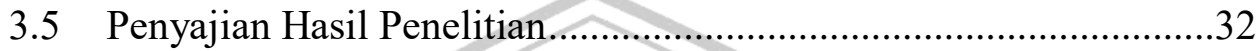

3.6 Penyajian Kesimpulan Penelitian...................................................32

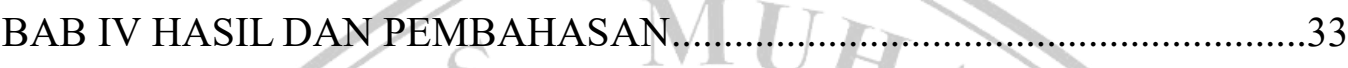

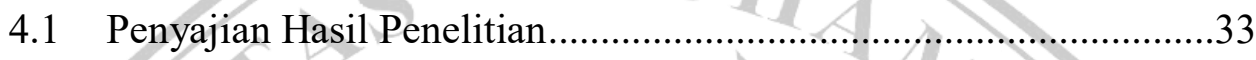

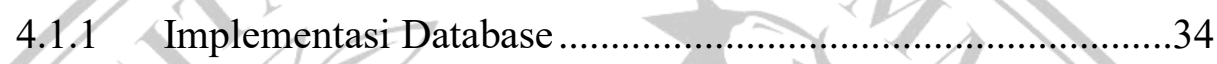

4.1.2 Implementasi Penulisan Kode Program................................34

4.1.2.1 Progres Penyusunan RPS ............................................34

4.1.2.2 Progres Penyusunan Seluruh Dosen.............................35

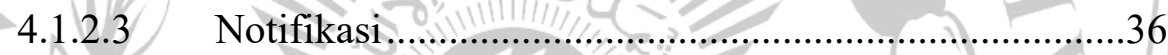

4.1.2.4 Halaman Progres Mata Kuliah Saya ...........................38

4.1.2.5 Halaman Progres Keseluruhan Dosen ..........................39

4.1.2.6 Halaman Notifikasi Pada Dasboard ...........................40

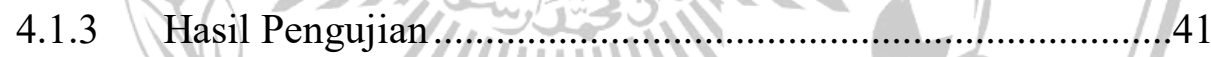

4.1.3.1 Hasil Pengecekan RPS Penguji ....................................41

4.1.3.2 Hasil Uji Sistem .................................................43

4.1.3.3 Hasil Nilai Uji RPS pada Sistem...............................47

4.1.3.4 Hasil Analisa Fenomena .............................................48

4.1.3.5 Pengecekan Fungsionalitas Sistem...............................48

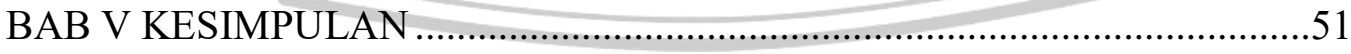

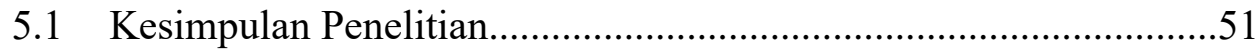

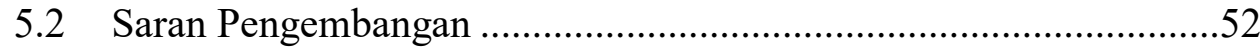

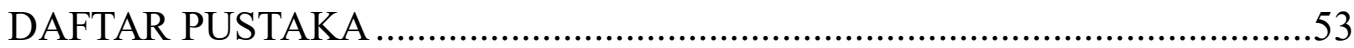

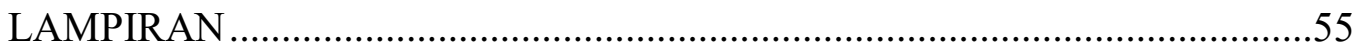

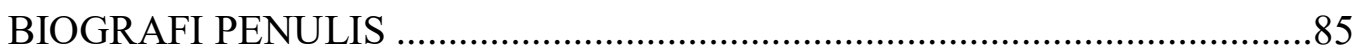




\section{DAFTAR GAMBAR}

Gambar 2.1 Pembelajaran sebagai Tahap Pelaksanaan RPS ..........................6

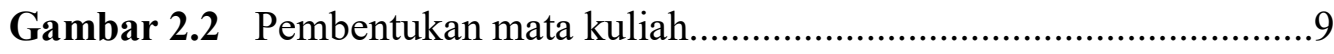

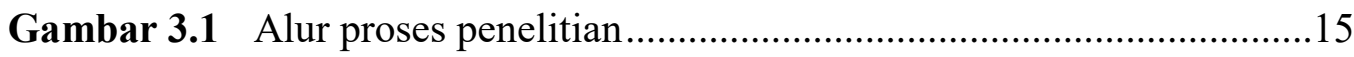

Gambar 3.2 Alur perancangan RPS (www.Lective.co.id) .............................16

Gambar 3.3 Model Proses Bisnis Penyusunan RPS (Awal) ...........................16

Gambar 3.4 Potongan Diagram Entitas Lective (www.Lective.co.id) ............17

Gambar 3.5 Model Proses Bisnis Setelah Perbaikan Proses 1 ........................18

Gambar 3.6 Model Proses Bisnis Setelah Perbaikan Proses 2 .......................19

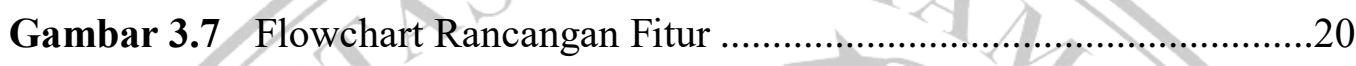

Gambar 3.8 Flowchart Pengecekan Kelengkapan Atribut .........................25

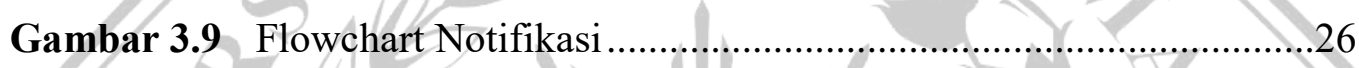

Gambar 3.10 Desain Antarmuka Progres Mata Kuliah Saya .........................22

Gambar 3.11 Desain Antarmuka Laporan Admin ......................................27

Gambar 3.12 Desain Antarmuka Notifikasi ............................................28

Gambar 3.13 Lembar Catatan Penilaian RPS ..............................................2

Gambar 3.14 Lembar Penilaian Komponen/Atribut RPS .............................30

Gambar 4.1 Penambahan Kolom Due Date pada Tabel Akun Prodi ...............34

Gambar 4.2 Halaman Progress Mata Kuliah Saya .........................................39

Gambar 4.3 Halaman Progress Seluruh Dosen ...........................................40

Gambar 4.4 Notifikasi pada Dashboard Dosen .........................................40

Gambar 4.5 Kolom Due Date pada Preferensi Akun Prodi...........................41

Gambar 4.6 Halaman dashboard sebelum menampilkan notifikasi................44

Gambar 4.7 Halaman Progres Mata Kuliah Saya........................................4

Gambar 4.8 Halaman progres RPS Semua Dosen ......................................45

Gambar 4.9 Halaman Preferensi Akun Prodi ...................................................45

Gambar 4.10 Pemilihan Bulan Due Date ........................................................45

Gambar 4.11 Pemilihan Tanggal Due Date ..................................................46

Gambar 4.12 Pemberitahuan berhasil mengubah data ....................................46

Gambar 4.13 Notifikasi muncul pada dashboard .........................................46 


\section{DAFTAR TABEL}

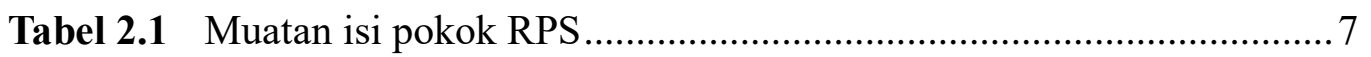

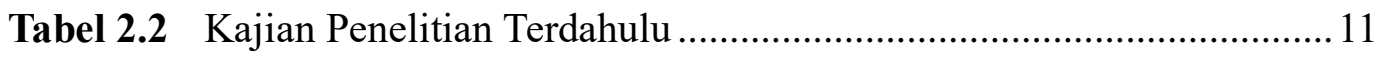

Tabel 3.1 Rancangan Rekomendasi Perbaikan .............................................. 18

Tabel 3.2 Atribut Acuan Kelengkapan RPS berdasarkan Analisis Kualitatif ...21

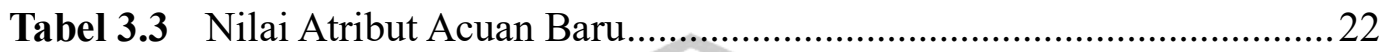

Tabel 3.4 Alasan Hilangnya Atribut Acuan..................................................... 23

Tabel 3.5 Rancangan Daftar Sumber RPS ..................................................... 31

Tabel 3.6 Rancangan Daftar Hasil Penilaian Pakar ......................................... 31

Tabel 3.7 Rancangan Perbandingan Hasil Sistem dan Pakar........................... 32

Tabel 4.1 Daftar Sumber RPS yang Diuji ................................................ 41

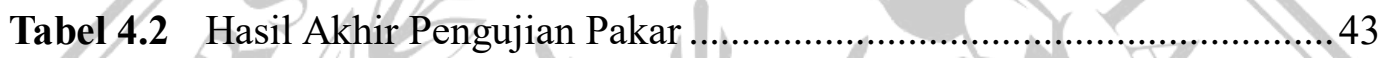

Tabel 4.3 Nilai Persentase yang dihasilkan Sistem.......................................47

Tabel 4.4 Hasil Perbandingan Persentase Sistem dan Pakar............................47

Tabel 4.5 Uji Fungsional Setelah Pengembangan 1 _....................................49

Tabel 4.6 Uji Fungsional Setelah Pengembangan 2 ................................... 50

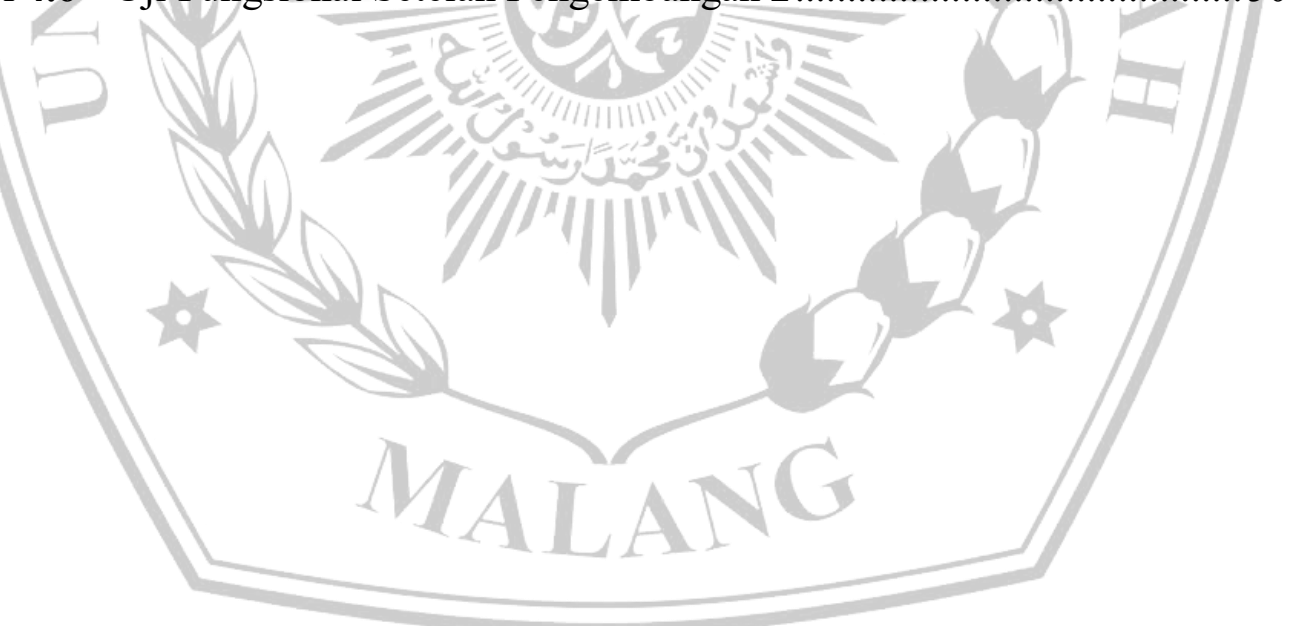




\section{DAFTAR LAMPIRAN}

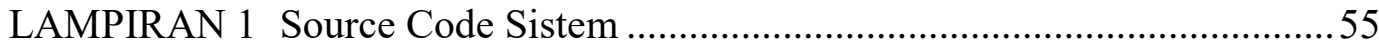

LAMPIRAN 2 Pokok Pertanyaan Wawancara Pakar .......................................... 61

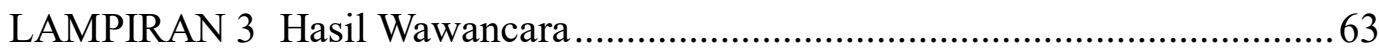

LAMPIRAN 4 Hasil Uji Dokumen RPS Pada Pakar ........................................6 65

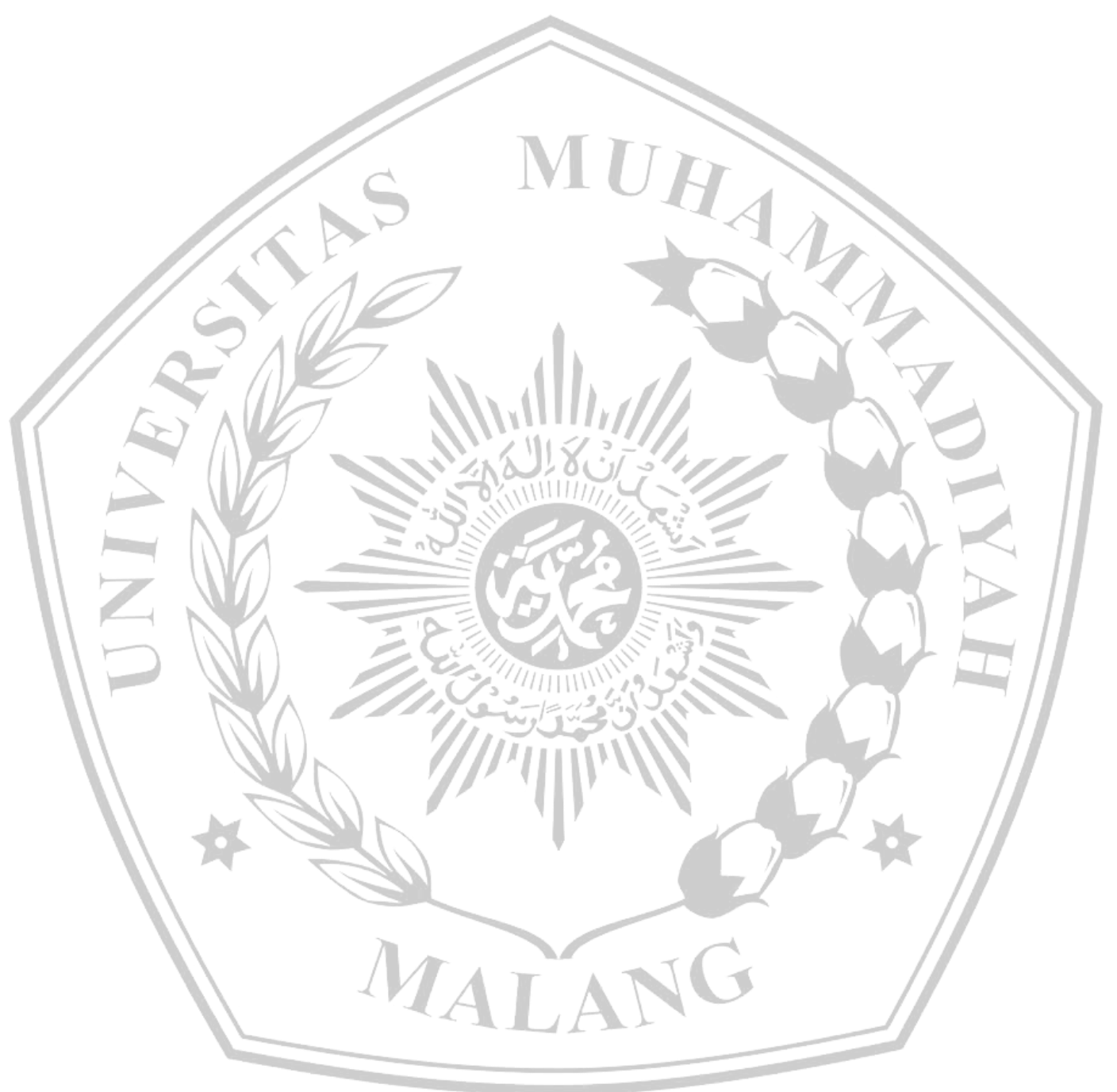




\section{DAFTAR PUSTAKA}

[1] H. D. F. Danang Hadi Asy'ari, Sheila Lugitha, "Jurnal Elektronik dan Buku Elektronik," Univ. Brawijaya, pp. 3-18, 2015.

[2] G. W. Wicaksono, H. W. Asrini, and M. A. Al-Rizki, "Desain Perangkat Pembelajaran Pendidikan Tinggi dengan Sistem Lective Gegulang ${ }^{\text {TM }}$," J. Nas. Tek. Elektro dan Teknol. Inf., vol. 6, no. 4, pp. 416-422, 2017, doi: 10.22146/jnteti.v6i4.353.

[3] G. W. Wicaksono, H. W. Asrini, and D. Iswatiningsih, "Desain Kurikulum Program Studi Teknik Informatika Universitas Muhammadiyah Malang dengan tools Lective Huluakan," Semin. Nas. dan Gelar Prod., pp. 432-440, 2017.

[4] G. I. Marthasari and N. Hayatin, "Analisis Usability Terhadap Sistem Lective Gegulang Berbasis USE Qestionnaire," J. Semin. Nas. Teknol. dan Rekayasa, vol. 1 , no. 1, pp. 1-8, 2017.

[5] M. A. Al-rizki, G. W. Wicaksono, and Y. Azhar, "The Analysis of Proximity Between Subjects Based on Primary Contents Using Cosine Similarity on Lective," Kinetik, vol. 2, no. 4, p. 299, 2017, doi: 10.22219/kinetik.v2i4.271.

[6] Menristekdikti, Panduan Penyusunan Kurikulum Pendidikan Tinggi, 2nd ed. Jakarta: Direktorat Jendral Pembelajaran dan Kemahasiswaan Kementrian Riset Teknologi dan Pendidikan Tinggi, 2016.

[7] H. Sofyan and A. Noviasari, “APLIKASI LAPORAN HASIL SURVEI NON SEISMIK BERBASIS WEB UNTUK KONTRAKTOR KONTRAK KERJA SAMA ( KKKS ) PADA BADAN PELAKSANA KEGIATAN USAHA HULU MINYAK DAN GAS,” vol. 2010, no. semnasIF, pp. 360 $369,2010$.

[8] P. Oktivasari and Z. F. Suhardi, "PENGEMBANGAN FITUR DOWNTIME REPORTING DAN MODUL SUMMARY PADA SISTEM MONITOR DAN PELAPORAN OPERASIONAL MESIN eCRM,” J. Tek. Inform., vol. 
9, no. 1, pp. 46-53, 2016, doi: 10.15408/jti.v9i1.5577.

[9] L. Bariyah, “Analisis Kesesuaian RPP dan Pelaksanaan Pembelajaran Guru SMP di Kabupaten Mojokerto pada Sub Materi Fotosintesis dengan Kurikulum 2013," J. BioEdu - Berk. Ilm. Pendidik. Biol. UNESA, vol. 3, no. 3, pp. 453-460, 2014.

[10] S. B. Utomo, "Business Process Improvement ( Bpi ) Proses Pengadaan Barang Non-Part Dengan Membangun E-Catalog ( Studi Kasus Di Pt . Tmmin )," Semin. Nas. Sist. Inf. Indones., no. November, 2018.

[11] S. Nurdin, "Pengembangan Kurikulum dan Rencana Pembelajaran Semester (RPS) Berbasis KKNI di Perguruan Tinggi," Murabby J. Pendidik. Islam, vol. 1, no. 2 , pp. $140-147,2019$, doi: $10.15548 / \mathrm{mrb} . v 1 \mathrm{i} 2.305$.

[12] M. W. Inderawati, R. Sukwadi, and H. A. Hutahaean, "Perbaikan Proses Bisnis Pengelolaan Data Penelitian pada Perguruan Tinggi: Sebuah Model Konseptual," Mediat. J. Teknol., vol. 11, no. 1, pp. 15-21, 2016.

[13] F. Pamungkas, T. Hariyanto, and E. Woro U, "Identifikasi Ketidaklengkapan Dokumen Rekam Medis Rawat Inap di RSUD Ngudi Waluyo Wlingi," $J$. Kedokt. Brawijaya, vol. 28 , no. 2, pp. 124-128, 2015, doi: 10.21776/ub.jkb.2015.028.02.2.

[14] A. Afrahamiryano, "Validitas Rencana Pembelajaran Semester Mata Kuliah Kimia Dasar Program Studi Pendidikan Biologi/Universitas Mahaputra Muhammad Yamin,” J. Eksakta Pendidik., vol. 2, no. 1, p. 49, 2018, doi: 10.24036/jep/vol2-iss1/136.

[15] F. Khairunnisa, "Evaluasi Komponen Kelayakan Isi Buku Ajar Bahasa Indonesia: Kesesuaian Materi dengan Kurikulum,”J. Penelit. Pendidik. Bhs. dan Sastra, vol. 4, no. 1, 2019. 


\section{SCAN SERTIFIKAT PLAGIASI}

\section{UNIVERSITAS MUHAMMADIYAH MALANG FAKULTAS TEKNIK}

PROGRAM STUDI TEKNIK INFORMATIKA

ת. Raya Tlogomas 246 Malang 65144 Telp. 0341 - 464318 Ext. 247, Fax. 0341 - 460782

\section{FORM CEK PLAGIARISME LAPORAN TUGAS AKHIR}

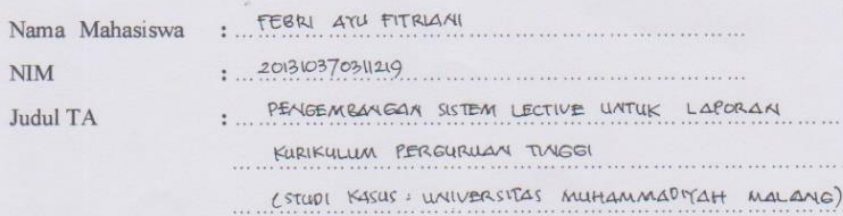

Hasil Cek Plagiarisme dengan Turnitin

\begin{tabular}{|l|l|c|c|}
\hline No. & \multicolumn{1}{|c|}{ Komponen Pengecekan } & $\begin{array}{c}\text { Nilai Maksimal } \\
\text { Plagiarisme (\%) }\end{array}$ & $\begin{array}{c}\text { Hasil Cek Plagiarisme } \\
\text { (\%) }\end{array}$ \\
\hline 1. & Bab 1 - Pendahuluan & $10 \%$ & $10 \%$ \\
\hline 2. & Bab 2 - Daftar Pustaka & $25 \%$ & $13 \%$ \\
\hline 3. & $\begin{array}{l}\text { Bab 3 - Analisis dan } \\
\text { Perancangan }\end{array}$ & $25 \%$ & $5 \%$ \\
\hline 4. & $\begin{array}{l}\text { Bab 4 - Implementasi dan } \\
\text { Pengujian }\end{array}$ & $15 \%$ & $3 \%$ \\
\hline 5. & $\begin{array}{l}\text { Bab 5 - Kesimpulan dan } \\
\text { Saran }\end{array}$ & $5 \%$ & $20 \%$ \\
\hline 6. & Makalah Tugas Akhir & & $15 \%$ \\
\hline
\end{tabular}

*) Hasil cek plagiarism diisi oleh salah satu pembimbing

**) Ditanda tangani Dosen Pembimbing atau Koordinator Cek Plagiarisme

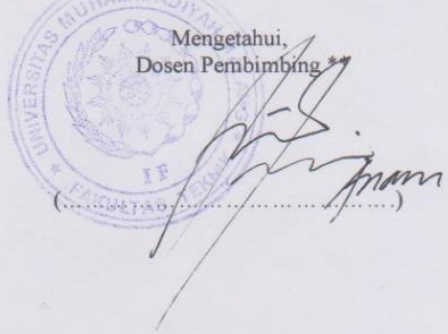

